Volume and Issues Obtainable at Center for Sustainability Research and Consultancy
Journal of Business and Social Review in Emerging Economies
ISSN: $2519-089 X(E): 2519-0326$
Volume $6:$ No. 4 , December 2020
CSRᄃ
Journal homepage: $\underline{\text { www.publishing.globalcsrc.org/jbsee }}$

\title{
Effect of Practices Executed by Monitoring Education Assistants on Elementary School Teachers' Mental Health
}

\author{
${ }^{1}$ Sumaira Munawar, ${ }^{2}$ Khadija Sittar, ${ }^{3}$ Misbah Malik
}

${ }^{1}$ Assistant professor, Lahore Leads University, Lahore, Pakistan, sumairamunawar16@gmail.com

${ }^{2}$ Institute of Education and Research, University of the Punjab, Lahore, Pakistan, khadijasittar@gmail.com

${ }^{3}$ Lecturer, Institute of Education and Research, University of the Punjab, Lahore, Pakistan, misbah.ier@pu.edu.pk

\begin{tabular}{|c|c|}
\hline ARTICLE DETAILS & ABSTRACT \\
\hline $\begin{array}{l}\text { History } \\
\text { Revised format: August } 2020 \\
\text { Available Online: September } \\
2020\end{array}$ & \multirow{7}{*}{$\begin{array}{l}\text { Teachers' mental health not only increases their efficiency, } \\
\text { professional growth and development but also their effects their } \\
\text { personality. Punjab education department established Monitoring } \\
\text { education authorities to improve quality of education by monitoring } \\
\text { quality indicators. Monitoring practices of Education Assistants may } \\
\text { affect the mental health of teachers on their workplaces which } \\
\text { culminate in low performance. The objective of this study was to } \\
\text { determine effect of monitoring education authorities' practices on } \\
\text { school teachers' mental health. } 300 \text { elementary school teachers were } \\
\text { selected for data collection through cluster sampling technique in } \\
\text { District Sheikhpura. Data collection was done through survey } \\
\text { questionnaire with } 17 \text { statements. Findings revealed that a significant } \\
\text { correlation between teachers performance and motivational } \\
\text { techniques used by their heads. A pilot study was conducted to } \\
\text { validate cronbach's alpha 0.86 which statistically significant. } \\
\text { Furthermore, following practices of Monitoring education authorities } \\
\text { are effecting mental health index. On the bases of these findings that } \\
\text { it is recommended that the government might give training to MEAs } \\
\text { for improving their behaviours during their visits in schools. }\end{array}$} \\
\hline Keywords & \\
\hline Monitoring & \\
\hline Assistants, & \\
\hline $\begin{array}{l}\text { School Teachers, Mental } \\
\text { Health }\end{array}$ & \\
\hline JEL Classification & \\
\hline$M 1, M 12$ & \\
\hline
\end{tabular}

\section{OPEN ACCESS}

(C) 2020 The authors, under a Creative Commons Attribution-NonCommercial 4.0

Corresponding author's email address: sumairamunawar16@gmail.com

Recommended citation: Munawar, S., Sittar, K. \& Malik, M. (2020). Effect of Practices Executed by Monitoring Education Assistants on Elementary School Teachers' Mental Health. Journal of Business and Social Review in Emerging Economies, 6(4), 1673-1679

\section{Introduction}

The socio-economic development of any country is based on the most important indicator called education. For a nations' socio-economic development it is a vital investment and given importance in all over the world. According to Government of Pakistan (2009) the role of education as a reform and development of a country is emphasized in all the education policies of Pakistan. In Pakistan there is no 
proper attention on quality of education. Total 2 percent of GDP is investing by the federal and provincial government which is very less to promote education in the country. World Bank (2004) described that in our country both quality and quantity of education is poor. This backwardness has many reasons. Some of them are poverty, lack of infrastructure, lack of funds and teachers' absenteeism. It is difficult in organizations of education to introduce the system of complex management in order to develop the means of modification for creation and formation of modern system(Sergeevich \& Sevastjanovna, 2020 ).

According to Muriuning (2015) "monitoring is a continuous process of collecting information, providing check and balance and presenting factual position of assigned work." The relevant information is gathered through monitoring process. "It is a type of evaluation that collects concrete information utilized for program reformation (Noh, 2006)". Mental health, in layman terms, is a "level of psychological well-being, or an absence of a mental disorder". According to various personnel and professional demands the level of mental heath being effected in teachers. The social, physical and mental health of teachers not only develop teachers' personality but it also adds to the teaches' efficiency. (Lucas \& Kate, 2019).

According to McCutcheon (2007) we have to remove these reasons in order to achieve national education goals. It is reviewed in the education policy of Pakistan recently that there are two main reasons (lack of commitment and implementation) because of them previous educational policies did not achieve the targets. Through motivation commitment gap might be filled and through better monitoring system implementation gap may be filled. Government of Pakistan (2009) recommended that in education sector monitoring system should be strengthen. The successful key to implementation of any educational program adequate, inclusive, rigorous, supervision and continuous monitoring are the most important elements. In order to assess implementation progress readily, there is need to some kind of mechanism for newly program introduced in any educational settings. This type of mechanism is called monitoring mechanism (Donkoh \& Dwamena, 2014).

Khawaja (2001) stated that activities of monitoring and supervision by monitoring education assistant within an educational system. "Monitoring is a type of evaluation that collects concrete information utilized for program reformation" (Noh, 2006). According to Shah (2009) "monitoring is a continuous process of collecting information, providing check and balance and presenting factual position of assigned work." The relevant information is gathered through monitoring. According to Shami (2009) monitoring involves results of communication at appropriate management level and for future evaluation of storage of information. For effective implementation of any program, monitoring is an effective part of management.

According to Tatnack (2000) "monitoring is an aspect of both accountability and development." There are two types of monitoring functions i.e. passive and active. Without proper monitoring any organization cannot be achieved their desired goals. Therefore, in all developed countries there is an effective and organized system of monitoring in the world. Shah (2004) defined that in order to ensure quality education effective monitoring is an important part of management system. The following steps involved in monitoring; objectives formulation, instrumentation, and aims of education. Through these steps it is ensured whether these objectives are achieved vigilantly or not. Many countries have their own monitoring system in all over the world. The monitoring education in Pakistan lies with the education department itself. The responsibility of monitoring school programs are the responsibility of heads who are the immediate boss of the institution. On the other hand EDOs, DEOs, DDEOs, and AEOs are responsible for planning, organizing, staffing, directing, leading, controlling, monitoring and evaluating the institutions.

Under the Punjab Education Sector Reforms Program (PESRP) in 2000, Government of the Punjab (2001) has reforms in education sectors. PESRP has three pillars responsible for quality education. In 2001 under the act of devolution power, provincial government introduced an external monitoring 
system called Program Monitoring and Implementation which was initiated to enhance quality of education, access to education, allocation of resources to support devolution and improve governance in Punjab at provincial and district level. The programs and projects of government of the Punjab are monitoring by the Monitoring and Implementation Unit (PMIU). In all thirty five districts there are appointed thirty five District Monitoring Officers (DMOs) for this purpose. "These DMOs had been appointed directly by the Chief Minister Secretariat after recommendation of services and general administration department of the provincial government and they were appointed from District Management Group." A sub department of monitoring cell PMIU called monitoring cell was established to monitoring educational programs.

In order to collect data from schools retired Junior Commissioned Officers of army (JCOs) were appointed. The designation given to these newly appointed field workers are called Monitoring and Evaluation Assistants (MEAs). The monthly reports are sent to District Monitoring Officers made by them. Then further copies of these reports forwarded to the DCO and Chief Minister of Punjab. According to the report given by DMOs it is the duty of DCO to give instructions to concerned education officer to take action on these reports. At district level under the DCO both departments are working. The data is gathered by monitoring system through public education system and third party validated the data. With the help of these stake holders (EDOEs, DEOs, DMOs and heads) through PESRP has to improve the Punjab province education system. Under the PESRP at primary and secondary level enrollment rate has been increased GOP, 2007).

Many factors like devolution of power, external and internal motivation, commitment and efforts of government and media campaigns are responsible for this gain. In order to take corrective actions, monitoring system provide facts and figures provided by these factors. There is need to find effectiveness of both systems working parallel to the both monitoring system. Mental health of teachers are affected by this strict monitoring system. Therefore, researcher intended to investigate the effect of monitoring evaluation on mental health of teachers.

\section{Research Questions}

Following research questions were formed in this study.

1. Is there any significant difference between male and female teachers about "Effect of Practices Executed by Monitoring Education Assistants on Elementary School Teachers' Mental Health"?

2. Is there any significant difference between rural and urban teachers about "Effect of Practices Executed by Monitoring Education Assistants on Elementary School Teachers' Mental Health?"

3. Is there any significant difference between B. Ed. And M. Ed. teachers about "Effect of Practices Executed by Monitoring Education Assistants on Elementary School Teachers' Mental Health?"

4. Is there any significant difference between PST and EST teachers about "Effect of Practices Executed by Monitoring Education Assistants on Elementary School Teachers' Mental Health?"

5. Is there any significant difference between teachers about "Effect of Practices Executed by Monitoring Education Assistants on Elementary School Teachers' Mental Health in terms of their qualification?"

6. Is there any significant difference between teachers about "Effect of Practices Executed by Monitoring Education Assistants on Elementary School Teachers' Mental Health in terms of their age?"

\section{Research Methodology}


Present study was quantitative in nature .The survey method was used to collect data. Population of the study was all the Government Elementary School teachers working in schools of District Sheikhpura. Sample of the study was 300 elementary school teachers.

\section{Instrumentation}

Questioner was used for data collection. The researcher used a self-compiled questionnaire for data collection. The questionnaire consisted of five point Likert scales. Responses of the items rated on five point likert type scale from 'strongly agree 5' to 'strongly Disagree1.

\section{Data Analysis}

Data were analysed by using inferential statistics (independent samples t-test).

\section{Table 1}

Comparison of Male and Female Teacher's' Perceptions regarding Effect of Practices

Executed by Monitoring Education Assistants on Elementary School Teacher's' Mental

Health

\begin{tabular}{llllllll}
\hline Variable & Gender & $N$ & $M$ & $S D$ & t-value & $d f$ & Sig. \\
& & & & & & & \\
\hline MEAS & Male & 121 & 57.09 & 11.34 & 4.872 & 298 & 0.094 \\
& Female & 179 & 50.21 & 12.42 & & & \\
Mental & Male & 121 & 49.39 & 7.90 & 0.859 & 296.885 & 0.003 \\
Health & Female & 179 & 50.40 & 12.47 & & & \\
\hline
\end{tabular}

The mean scores regarding the perceptions of male and female teachers about "Effect of Practices Executed by Monitoring Education Assistants on Elementary School Teachers' Mental Health" was shown in table 1.No significant mean difference between male and female teachers' was found at $p \leq 0.05$ level of significance. Whereas, male and female teachers have mean difference regarding mental health at $\mathrm{p} \leq 0.05$ significance level.

Table 2

Comparison of Teachers' Perceptions regarding Effect of Practices Executed by Monitoring Education Assistants on Elementary School Teachers' Mental Health in terms of Local

\begin{tabular}{llllllll}
\hline Variable & Area & $N$ & $M$ & $S D$ & t-value & $d f$ & Sig. \\
\hline MEAS & Rural & 172 & 54.21 & 12.67 & 1.980 & 298 & 0.775 \\
& Urban & 128 & 51.35 & 11.99 & & & \\
Mental & Rural & 172 & 49.05 & 7.99 & 1.625 & 190.048 & 0.001 \\
Health & Urban & 128 & 51.26 & 13.73 & & & \\
\hline
\end{tabular}

The mean scores regarding the perceptions of rural and urban teachers about "Effect of Practices Executed by Monitoring Education Assistants on Elementary School Teachers' Mental Health" was shown in table 2. A significant mean difference between male and female teachers' was found at $\mathrm{p} \leq 0.05$ 
level of significance. Whereas, rural and urban teachers have mean difference regarding mental health at $\mathrm{p} \leq 0.05$ level of significance.

\section{Table 3}

Comparison of Teachers' Perceptions regarding Effect of Practices Executed by Monitoring Education Assistants on Elementary School Teachers' Mental Health in terms of Professional Qualification

\begin{tabular}{llllllll}
\hline Variable & PQ & $N$ & $M$ & $S D$ & t-value & $d f$ & Sig. \\
\hline MEAS & B.Ed. & 171 & 52.67 & 13.67 & 0.820 & 294.887 & 0.001 \\
& M.Ed. & 126 & 53.81 & 10.26 & & & \\
Mental & B.Ed. & 171 & 48.46 & 9.32 & 2.964 & 295 & 0.525 \\
Health & M.Ed. & 126 & 52.20 & 12.41 & & & \\
\hline
\end{tabular}

The mean scores regarding the perceptions of B.Ed and M.Ed. teachers about "Effect of Practices Executed by Monitoring Education Assistants on Elementary School Teachers' Mental Health" was shown in table 3. A significant mean difference between B.Ed and M.Ed. teachers' was found at $\mathrm{p} \leq 0.05$ level of significance. Whereas, B. Ed. and M.Ed. teachers have no mean difference regarding mental health at $\mathrm{p} \leq 0.05$ significance level.

Table 4

Comparison of Teachers' Perceptions regarding Effect of Practices Executed by Monitoring Education Assistants on Elementary School Teachers' Mental Health in terms of Designation

\begin{tabular}{llllllll}
\hline Variable & Designation & $N$ & $M$ & $S D$ & t-value & $d f$ & Sig. \\
\hline MEAS & EST & 151 & 53.60 & 12.40 & 0.763 & 297 & 0.889 \\
& PST & 148 & 52.51 & 12.42 & & & \\
Mental & EST & 151 & 50.58 & 9.49 & 0.828 & 297 & 0.665 \\
Health & PST & 148 & 49.54 & 12.01 & & & \\
\hline
\end{tabular}

The mean scores regarding the perceptions of PST and EST teachers about "Effect of Practices Executed by Monitoring Education Assistants on Elementary School Teachers' Mental Health" was shown in table 4. No significant mean difference between PST and EST teachers' was found at $p \leq 0.05$ level of significance. Whereas, PST and EST teachers have no mean difference regarding mental health at $p \leq 0.05$ level of significance. 


\section{Table 5}

Comparison of Teachers' Perceptions regarding Effect of Practices Executed by Monitoring Education Assistants on Elementary School Teacher's' Mental Health in terms of Age

\begin{tabular}{llllll}
\hline Variable & Sum of Square & Mean Square & $F$ & $d f$ & Sig. \\
\hline MEAS & 168.753 & 84.377 & 0.543 & 2 & 0.582 \\
& 46175.234 & 155.472 & & 297 & \\
& 46343.987 & & & 299 & \\
Mental Health & 152.168 & 76.084 & 0.644 & 2 & 0.526 \\
& 35097.832 & 118.175 & & 297 & \\
& 35250.000 & & & 299 & \\
\hline
\end{tabular}

Age wise mean scores regarding the perceptions of male and female teachers about "Effect of Practices Executed by Monitoring Education Assistants on Elementary School Teachers' Mental Health" was shown in table 5. "No significant mean difference between male and female teachers' was found at $\mathrm{p} \leq 0.05$ level of significance". Whereas, male and female teachers have no mean difference regarding mental health at $\mathrm{p} \leq 0.05$ level of significance.

\section{Table 6}

Comparison of Teachers' Perceptions regarding Effect of Practices Executed by Monitoring Education Assistants on Elementary School Teachers' Mental Health in terms of Qualification

\begin{tabular}{llllll}
\hline Variable & $\begin{array}{l}\text { Sum of } \\
\text { Square }\end{array}$ & $\begin{array}{l}\text { Mean } \\
\text { Square }\end{array}$ & $F$ & $d f$ & Sig. \\
\hline Qualification & 141.759 & 70.880 & 0.456 & 2 & 0.634 \\
& 46202.227 & 155.563 & & 297 & \\
& 46343.987 & & & 299 & \\
Qualification & 105.410 & 52.705 & 0.445 & 2 & 0.641 \\
& 35144.590 & 118.332 & & 297 & \\
& 35250.000 & & & 299 & \\
\hline
\end{tabular}

Qualification wise mean scores regarding the perceptions of male and female teachers about "Effect of Practices Executed by Monitoring Education Assistants on Elementary School Teachers' Mental Health" was shown in table 6. "No significant mean difference between male and female teachers' was found at $\mathrm{p} \leq 0.05$ level of significance". Whereas, male and female teachers have no mean difference regarding mental health at $p \leq 0.05$ level of significance.

\section{Conclusions}

On the basis of data analyses, the following conclusions are drawn.

1. MEAs checked the balance/record of School Council (SC), Farogh-e-Taleem funds.

2. "MEAs also reviewed the number of meetings held during the past three months by the school board and the visit by the District Officer and the Deputy District Education Officer." 
3. The necessary equipment would be tested by MEAs like, cleanliness of building, parks, and school playgrounds and classroom environment.

4. This monitoring system for the improvement of primary education system is valuable.

5. Daily three to four hour MEAs should visit by MEAs regularly in schools.

6. School monitoring training did not received by MEAs.

7. Before visit to any school deputy district education officer did not inform by MEAs before the visit to any school.

8. Head-teachers provide co-operation to MEAs during their visit to school.

9. Number of students present and absent in the class should be checked by the MEAs at the time of monitoring and also check Farogh-e-Taleem fund received per student.

10. MEAs examined the students ' level of cleanliness and a number of free sets of textbooks.

\section{Recommendations}

Following were the recommendations on the basis of the above findings.

1. Monitoring education authorities receive no school trainings. Therefore, MEAs should provide training before the 15 days of their appointments and an orientation session should be conducted.

2. Before visiting to any school MEAs should informed by District Education Officer / Deputy District Education Officer, therefore, the visit schedule should be provided to the District Education Officer/ Deputy District Education Officer by MEAs.

\section{References}

Donkoh,E.K., \& Dwamena, E.O.(2014). Effects of educational supervision on professional development : perception Of public basic school teachers at Winneba,Ghana. British Journal of Education,1(6),63-82.

Government of Pakistan (2009).National Education Policy. Islamabad: Ministry of Education.

Government of Punjab (2007).Punjab in Figures 2007. Lahore: Planning and Development Department.

Lucas,S., \& Kate,H. (2019).Secondary school teachers' experiences of supporting mental health. Journal of Mental Health Trainning Education and Practice,14(5),372-383.

McCutcheon, S. (2007).Punjabi Reforms. Retrieved from www.UNDP.org/pk dated 04/03/2010.

Muriungi, M.T. (2015). The role of participatory monitoring and evaluation programs among government corporations: a case of Ewaso Ngi'ro North Development Authority. International Academic Journal of Social Sciences and Education,1(4), 53-76.

Noh, H. J. (2006). Policy Evaluation (2nd ed.). Bupmunsa: Seoul, Korea.

Shah, D. (2009).Monitoring the Quality of Secondary Education in Context of Decentralization in Pakistan.Lahore.Bulletin of Education and Research, 31(1), 1-25. IER, University of the Punjab. Shami, P.A. (2009). Educational Leadership and Institutional Management. Islamabad: AEPM, MOE. World Bank. (2004). Making Service Work for Poor People. World Development Report, Washington and Oxford: World Bank and Oxford University Press. 